\title{
Sistem Pakar Pendeteksi Kerusakan Handphone Berbasis Android
}

\author{
Mercydian Pangkey $^{(1)}$, Vecky Poekoel ${ }^{(2)}$, Oktavian Lantang ${ }^{(3)}$ \\ Teknik Informatika, Universitas Sam Ratulangi, Manado, Indonesia. \\ Email: maimunaobit@gmail.com, vecky_poekoel@unsrat.ac.id, oktavian_lantang@unsrat.ac.id
}

\begin{abstract}
Abstrak --- Handphone tidak hanya memiliki fungsi untuk menelepon dan mengirim pesan. Pada beberapa handphone kelas atas (smartphone) bahkan hampir memiliki fungsi seperti komputer. Dengan adanya handphone sangat membantu kelancaran kegiatan manusia. Akan tetapi, hanya sedikit dari orang yang memakai handphone yang peka akan gejala - gejala kerusakan pada handphone, sehingga kebanyakan orang tidak sadar dan cuek akan gejala kerusakan tersebut hingga handphone tersebut benar-benar mati. Karena hal itulah dibutuhkan suatu perangkat lunak yang berupa aplikasi program atau sistem pakar yang sesuai dengan permasalahan yang terjadi pada handphone.

Sistem pakar merupakan kecerdasan buatan yang menggabungkan pengetahuan dan penelusuran data untuk memecahkan masalah yang secara normal memerlukan keahlian manusia. Tujuan dari penelitian ini adalah membuat aplikasi sistem pakar berbasis android dalam mendeteksi kerusakan handphone. Dengan menggunakan teknik penalaran forward chaining, deteksi dilakukan dengan memulai dari sekumpulan gejala-gejala, nantinya dapat melihat kesimpulan jenis kerusakan pada handphone. Metode yang digunakan sebagai tahapan penelitian ini adalah metode Extreme Programming (XP) yang merupakan metode rancang bangun perangkat lunak yang menekankan pada 4 tahapan dalam pengembangan perangkat lunak.
\end{abstract}

Kata Kunci: Handhpone, Sistem Pakar, Forward Chaining, Extreme Programming

\section{PENDAhUluan}

Handphone atau biasa disebut dengan telepon genggam yang dahulu termasuk barang mewah, namun dengan seiring berkembangnya zaman dan semakin bertambahnya perusahaan pembuat handphone, membuat harga handphone semakin murah sehingga hampir semua orang bisa memilikinya. Bahkan tidak jarang dari mereka memiliki handphone lebih dari satu.

Seiring berkembangnya teknologi saat ini handphone tidak hanya memiliki fungsi untuk menelepon dan mengirim pesan. Pada beberapa handphone kelas atas (smartphone) bahkan hampir memiliki fungsi seperti komputer. Dengan adanya handphone sangat membantu kelancaran kegiatan manusia. Akan tetapi, hanya sedikit dari orang yang memakai handphone yang peka akan gejala - gejala kerusakan pada handphone, seperti kerusakan IC Power, LCD, memori, keypad, speaker, Bluetooth dan lain-lain sehingga kebanyakan orang tidak sadar dan cuek akan gejala kerusakan tersebut hingga handphone tersebut benar-benar mati.

Kerusakan - kerusakan pada sebuah handphone sering kali mengganggu pengguna handphone, sehingga penggunanya hanya membawa handphone tersebut ke service handphone untuk mengetahui kerusakan apa yang terjadi pada perangkat tersebut. Waktu perbaikan yang habis terpakai selama handphone pengguna di tempat service juga dapat menyita waktu pengguna. Belum juga biaya yang akan dikeluarkan untuk memperbaiki perangkat tersebut serta penipuan yang banyak terjadi dikala kita membawa handphone ke tempat service.

Berdasarkan permasalahan diatas, dibutuhkan suatu aplikasi yang dapat menghasilkan pengetahuan untuk menangani masalah yang timbul dari kerusakan handphone. Aplikasi yang dibuat harus mampu menangani masalah jarak, waktu, tenaga dan biaya yang dikeluarkan serta mudah digunakan bagi seluruh kalangan pengguna handphone.

Salah satu sistem operasi mobile yang digunakan oleh smartphone adalah Android. Android adalah sebuah sistem operasi untuk smartphone yang berbasis Linux. Kelebihan Android dibanding sistem operasi mobilephone atau smartphone lainnya adalah Android bersifat open source code sehingga memudahkan para pengembang untuk menciptakan dan memodifikasi aplikasi atau fitur - fitur yang belum ada di sistem operasi Android sesuai dengan keinginan mereka sendiri.

Maka dari itu sebagai upaya, diterapkan pembuatan Sistem Pakar Pendeteksi Kerusakan Handphone Berbasis Android. Dengan banyaknya pengguna handphone canggih (Smartphone) saat ini, dapat membantu para pengguna untuk lebih memahami lagi akan setiap gejala kerusakan pada handphone agar terhindar dari berbagai macam hal yang tidak diinginkan.

\section{LANDASAN TEORI}

\section{Sistem Pakar}

Menurut Kusumadewi (2003), sistem pakar adalah suatu cabang dari Artificial Intelligence yang berusaha mengadopsi pengetahuan manusia ke komputer agar dapat menyelesaikan masalah seperti yang biasa diselesaikan oleh para pakar. Dengan adanya sistem ini, orang awam pun dapat menyelesaikan masalah yang rumit yang sebenarnya hanya dapat diselesaikan oleh para ahli. Sedangkan bagi para ahli, sistem pakar dapat membantu aktivitasnya sebagai asisten yang berpengetahuan. Ada beberapa dasar mengapa sistem pakar menggantikan seorang pakar diantaranya adalah : [1]

1. Dapat menyediakan kepakaran setiap waktu diberbagai lokasi

2. Secara rutin mengerjakan tugas-tugas rutin yang membutuhkan seorang pakar

3. Seorang pakar akan pensiun atau pergi

4. Seorang pakar adalah mahal 
5. Kepakaran juga dibutuhkan pada lingkungan yang tidak bersahabat (hostile environment)

Dengan demikian seorang awam sekalipun bisa menggunakan sistem pakar itu untuk memecahkan berbagai persoalan yang ia hadapi dan bagi seorang ahli, sistem pakar dapat dijadikan alat untuk menunjang aktivitasnya yaitu sebagai asisten yang berpengalaman.

\section{Mesin Inferensi}

Menurut Turban menyebutkan mesin inferensi adalah program komputer yang memberikan metedologi untuk penalaran tentang informasi yang ada dalam basis pengetahuan dan dalam workplace, dan untuk merumuskan kesimpulan. Terdapat dua pendekatan dalam mengontrol inferensi dalam sistem pakar berbasis aturan, yaitu :[4]

- Pelacakan kedepan (fordward chaining)

Pelacakan kedepan adalah pendekatan yang terkendalidata (data-driven). Dalam pendekatan ini pelacakan dimulai dari informasi masukan, dan selanjutnya mencoba menggambarkan kesimpulan. Pelacakan ke depan mencari fakta yang sesuai dengan bagian if dari aturan if-then.

- Pelacakan kebelakang (backward chaining)

Pelacakan kebelakang adalah pendekatan terkendalitujuan (goal driven). Dalam pendekatan ini, pelacakan dimulai dari tujuan selanjutnya dicari aturan yang memiliki tujuan tersebut untuk tujuannya.[4]

\section{Android}

Android merupakan sistem operasi bergerak (mobile operating system) yang mengadopsi sistem operasi linux, namun telah dimodifikasi. Android diambil alih oleh google pada tahun 2005 dari android. Ini sebagai bagian strategi untuk mengisi pasar sistem operasi bergerak. Google mengambil alih seluruh hasil kerja android termasuk tim yang mengembangkan android. Secara garis besar sistem operasi android menjadi 5 tingkatan:[3]

a) Linux Kernel

Linux kernel adalah kernel dasar dari android. Tingkat ini berisi semua driver perangkat tingkat rendah untuk komponen-komponen perangkat android.

b) Libraries

Libraries berisi semua kode program yang menyediakan layanan-layanan utama sistem operasi android.

c) Android Runtime

Android runtime kedudukannya sama dengan libraries, android runtime menyediakan kumpulan pustaka inti yang dapat diaktifkan oleh pengembang untuk menulis kode aplikasi dengan bahasa pemrograman java.

d) Application Framework

Tingkat dimana proses pengerjaan pembuatan aplikasi dilakukan..[3]

\section{Extreme Programming}

Model proses ini diciptakan dan dikembangkan oleh Kent Beck. Extreme Programming (XP) adalah sebuah pendekatan atau model pengembangan perangkat lunak yang mencoba menyederhanakan berbagai tahapan dalam proses pengembangan tersebut sehingga menjadi lebih adaptif dan fleksibel. Walaupun menggunakan kata programming, XP tidak hanya terfokus pada coding tetapi meliputi seluruh area pengembangan perangkat lunak.

Menurut Kent Beck, XP ringan, efisien, resiko rendah, mudah disesuaikan, dapat diprediksi, ilmiah dan mudah dikembangkan. Suatu model yang menekankan pada keterlibatan user secara langsung. [2]

\section{III.METODOLOGI PENELITIAN}

\section{Kerangka Pemikiran}

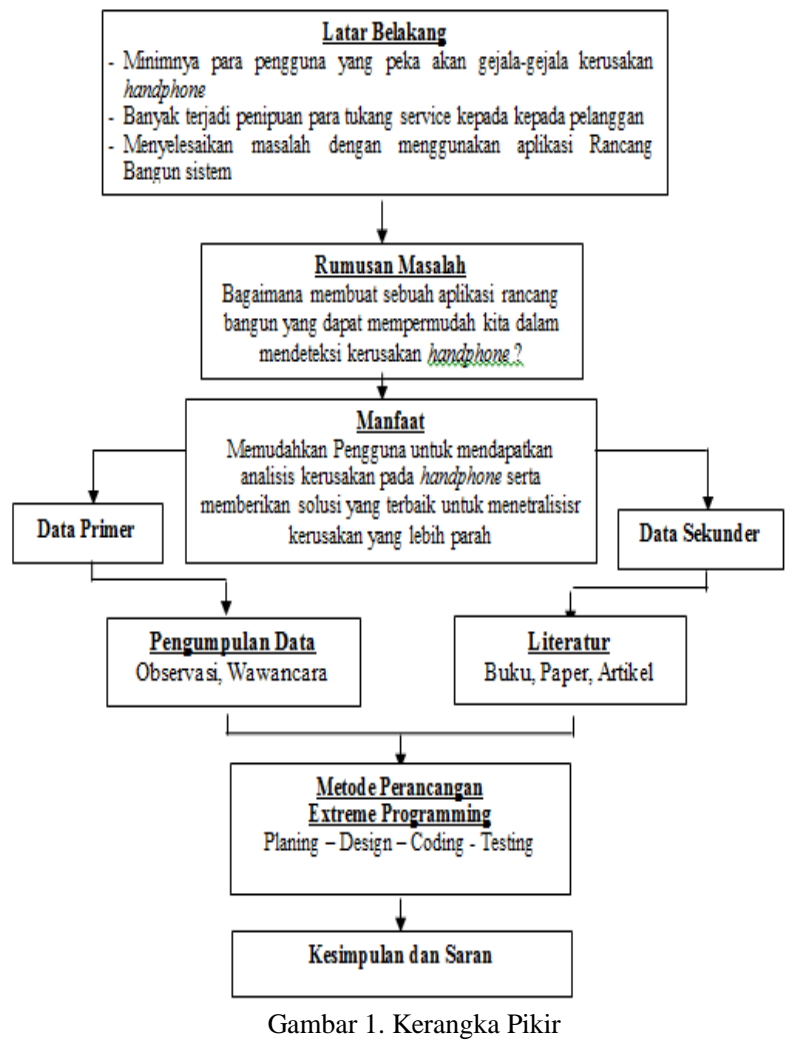

\section{Metode Perancangan Sistem}

Dalam metode perancangan sistem ini, penulis menggunakan metode Extreme Programming (XP). Model proses extreme programming terbentuk dari sebuah kerangka kerja yang memiliki 4 konteks aktivitas utama, yaitu :

1. Planning.

Aktivitas planning pada model proses XP berfokus pada mendapatkan gambaran fitur serta fungsi dari perangkat lunak yang akan dibangun. Pada aktivitas ini dimulai dengan membuat kumpulan cerita atau gambaran yang diberikan klien yang kemudian akan menjadi gambaran dasar dari perangkat lunak

2. Design

Proses desain pada XP mengikuti prinsip KIS (Kieep It Simple). Desain akan berisikan semua implementasi dari stories tanpa ada pengurangan maupun penambahan. Desain yang memiliki fungsi tambahan tidak disarankan. $X P$ menggunakan $C R C$ (Class-Responsibility-Collaborator) Cards untuk mengidentifikasi dan mengorganisasikan kelas berorientasi objek yang berkaitan dengan proses pengembangan software. Jika terdapat kesulitan untuk melakukan desain terhadap stories, $X P$ menyarankan untuk membuat prototype dari desain tersebut. Hal ini disebut sebagai spike solution, 
prototype nantinya akan diimplementasikan dan dievaluasi. Perubahan desain dapat terjadi walaupun sudah memasuki tahap coding/ implementasi. Hal tersebut dilakukan untuk mendapat desain yang baik dan kode yang bersih.

\section{Coding}

Setelah menyelesaikan pengumpulan cerita dan menyelesaikan design untuk aplikasi secara keseluruhan, XP lebih merekomendasikan tim untuk terlebih dahulu membuat modul unit tes yang bertujuan untuk melakukan uji coba setiap cerita yang didapat dari klien. Setelah berbagai unit tes selesai dibangun, tim barulah melanjutkan aktivitasnya ke penulisan coding aplikasi. XP menerapkan konsep pair programming dimana setiap tugas sebuah modul dikembangkan oleh dua orang programmer. XP beranggapan, 2 orang akan lebih cepat dan baik dalam menyelesaikan sebuah masalah. Selanjutnya, modul aplikasi yang sudah selesai dibangun akan digabungkan dengan aplikasi utama.

\section{Testing}

Setelah semua modul telah dikumpulkan dalam sebuah sistem yang sempurna, barulah pengujian penerimaan (acceptance test) dilakukan. Pada tahapan pengujian ini aplikasi langsung diuji coba oleh pengguna atau klien dan mendapat tanggapan langsung mengenai penerapan cerita yang telah digambarkan sebelumnya.

\section{Definisi dan Aturan Gejala Kerusakan}

Dalam pembahasan ini akan menjelaskan data mentah mengenai jenis-jenis kerusakan dan gejalanya yang ada pada handphone. Data inilah yang nantinya akan dibuat program dan didahului dengan adanya relasi data antara gejala dan kerusakan yang yang terjadi.

1. Data Gejala Kerusakan

Dibawah ini adalah daftar gejala-gejala semua jenis kerusakan yang terjadi :

Table 1. Daftar Kerusakan

\begin{tabular}{|l|l|}
\hline Kode & Jenis Kerusakan \\
\hline Q1 & Tidak Bisa Cars \\
\hline Q2 & LCD Bergaris \\
\hline Q3 & Insert SIM \\
\hline Q4 & $\begin{array}{l}\text { Pada saat melakukan panggilan, hp langsung } \\
\text { mati }\end{array}$ \\
\hline Q5 & Mati total \\
\hline Q6 & Bercak hitam pada LCD \\
\hline Q7 & Lampu LCD berkedip-kedip \\
\hline Q8 & Penekanan pada huruf menjadi acak \\
\hline Q9 & Data tiba-tiba hilang \\
\hline Q10 & Tulisan bergaris/ berantakan \\
\hline Q11 & Sebagian tombol tidak berfungsi \\
\hline Q12 & Tidak bisa diakses pada computer atau laptop \\
\hline Q13 & LCD blank/ mati \\
\hline Q14 & Layar tidak jelas \\
\hline Q15 & Sebagian tombol sulit ditekan \\
\hline Q16 & Tidak dapat membuka gallery pada HP \\
\hline Q17 & Koneksi Bluetooth sering gagal dan terputus \\
\hline Q18 & Kinerja HP lambat dan tidak optimal \\
\hline Q19 & HP tidak dapat booting ke menu \\
\hline
\end{tabular}

\begin{tabular}{|l|l|}
\hline Q20 & HP hidup mati sendiri \\
\hline Q21 & Hanya bisa mengirim file tertentu saja \\
\hline G22 & Sinyal hilang tiba-tiba \\
\hline G23 & $\begin{array}{l}\text { Saat mengaktifkan blueetoth HP menjadi hang } \\
\text { atau macet total }\end{array}$ \\
\hline G24 & Hanya bisa menerima file tertentu saja \\
\hline G25 & HP tiba-tiba mati padahal isi baterai masih ada \\
\hline G26 & Saat Bluetooth diaktifkan, HP terestart sendiri \\
\hline G27 & Tidak ada reaksi ketika ditekan \\
\hline
\end{tabular}

\section{Data Kerusakan Handphone}

Pada bagian ini di sajikan daftar kerusakan yang sering terjadi pada handphone secara umum. Daftar nama kerusakan ini di beri nomor urut otomatis, saya menggunakan ' $A$ ' untuk urutan pertama, ' $B$ ' untuk urutan kedua dan seterusnya

Tabel 2. Daftar Kersakan Handphone

\begin{tabular}{|c|c|}
\hline Kode & Jenis Kerusakan \\
\hline A & IC Power \\
\hline B & LCD \\
\hline C & Keypad \\
\hline D & Memory \\
\hline E & Baterai \\
\hline F & Bluetooth \\
\hline
\end{tabular}

3. Representasi Pengetahuan

Representasi pengetahuan yang akan digunakan dalam sistem pakar ini adalah dengan menggunakan jaringan semantik, pohon keputusan, dan kaidah produksi. Representasi pengetahuan dapat menemukan solusi atau memberikan penalaran yang tepeat dalam pengambilan kesimpulan.

a. Jaringan Semantik

Suatu proses terhadap basis pengetahuan atau informasi yang didapat dari pakar, terlebih dahulu diubah kedalam bentuk jaringan semantik. Jaringan semantik menunjukkan hubungan antara gejala dan kerusakan.

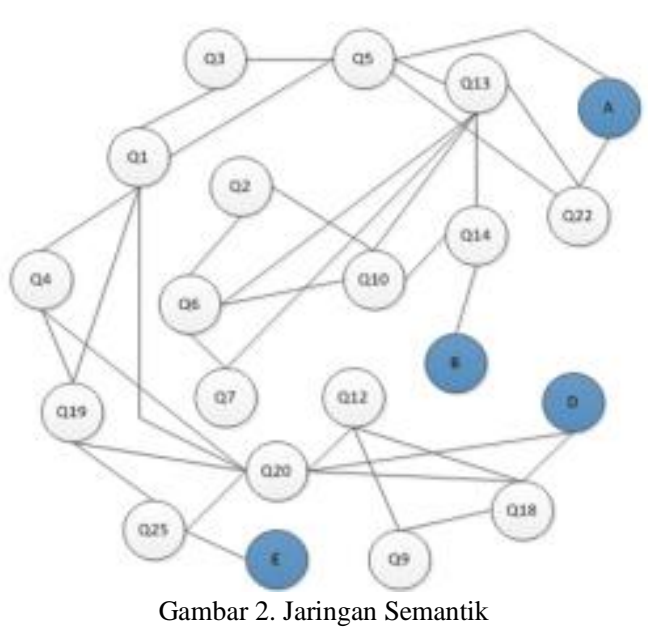

b. Pohon Keputusan

Setelah proses terhadap basis pengetahuan telah diubah kedalam bentuk jaringan semantik, selanjutnya diubah kedalam bentuk pohon keputusan, sehingga didalam penyelesaian masalah 
lebih mudah dilakukan penelusuran untuk mendapatkan solusi atau kesimpulan akhir yang terbaik.

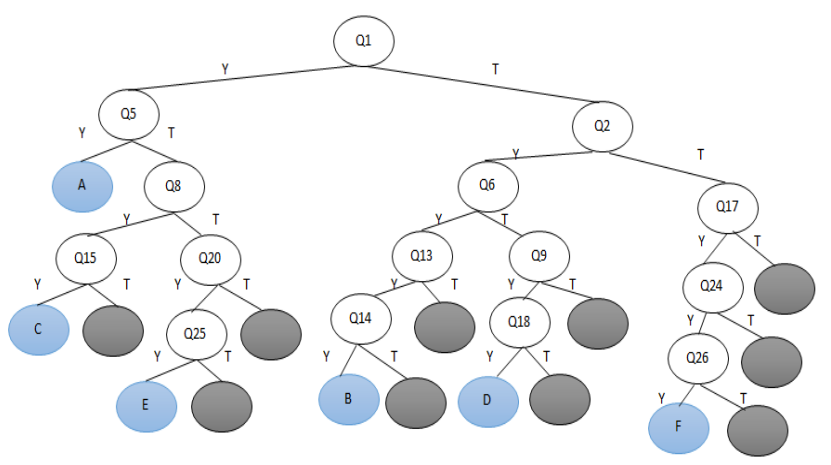

Gambar 3. Pohon Keputusan

\section{IV.HASIL DAN PEMBAHASAN}

Pada bab ini, akan dibahas secara detail dan terperinci mengenai sistem yang akan penulis bahas dengan menerapkan metode pengembangan sistem Extreme Programming $(X P)$ sebagai proses modelnya. Metode ini menekankan suatu pendekatan interaktif dari proses pengembangan perangkat lunak yang dimaksud untuk mengurangi resiko pada aplikasi dan memaksimalkan hasil akhir dari sebuah aplikasi. Optimalisasi juga dilakukan pada bagian teknologi perangkat lunak pendukung dengan cara menggunakan API (Application Programming Interface) dan Framework open source sehingga penullis bisa lebih focus pada ide dan konsep bisnis proses. Focus pada ide dan konsep bisnis proses memberikan ruang lebih banyak pada penulis untuk mencurahkan gagasan-gagasan baru dan kemudian dapat menghasilkan API, module dan teknikteknik baru sehingga bisa terbebas dari paradigma reinvent the wheel. API dan Framework diperoleh dari www.codeplex.com yang merupakan repository hasil komunitas pengguna teknologi berbasis Microsoft. Adapun tahapan yang dilakukan dan dijelaskan antara lain

\section{Tahap Planning}

Tahapan planning pada XP merupakan tahapan awal dari semua proses pengembangan sistem. Tahapan ini merupakan gabungan dari tahap analisis dan planning pada metode pengembangan klasik. Tahap planning dapat diketahui gambaran besar dari aplikasi yang hendak dikembangkan dan teknologi-teknologi pendukung yang akan.

\section{a. Use Case}

Use case ini menggambarkan tentang interaksi antara actor (user) dengan system. Disini digambarkan actor (user) melakukan beberapa kegiatan seperti melihat gejala, melihat hasil, melihat solusi, meihat tentang aplikasi dan keluar

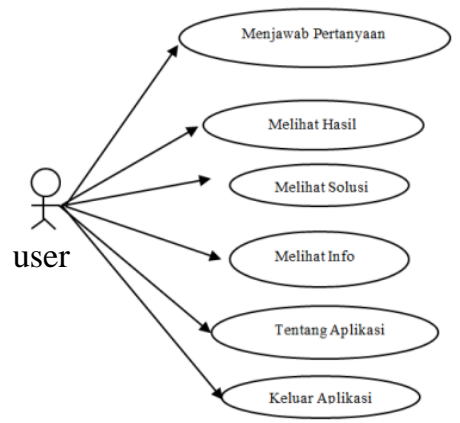

Gambar 4. Use Case

\section{b. User Stories}

Dari penjelasan analisis use case di atas, penulis dapat menyimpulkan melalui user stories sebagai berikut

1. User dapat menjawab pertanyaan dari gejala kerusakan handphone

2. User dapat melihat hasil dari gejala kerusakan yang dipilih

3. User dapat melihat Solusi dari hasil kerusakan yang terjadi

4. User dapat melihat Info dari hasil kerusakan yang terjadi

5. User dapat melihat 'Tentang Aplikasi'

6. User dapat Keluar dari aplikasi

\section{Tahap Desain}

DalamDalam mendesain aplikasi ini penulis menggunakan pendekatan yaitu membuat class design dan GUI design. Maksudnya adalah untuk mempermudah dan mempercepat penyelesaian proses desain. Penulis juga berusaha membuatnya sangat detail supaya pada saat proses pengkodean lebih mudah karena gambaran fungsi-fungsinya sudah jelas.

\section{Design CRC Card}

Proses desain pada tahap ini yaitu menggunakan CRC Responsibilities, and Collaboration (CRC) card. Penggunaan CRC card hanya dipakai jika pengembangan software berbasis objek. Setiap CRC card akan menjelaskan tiap objek yang dibutuhkan. Table 3. CRC Card

Class : Pertanyaan

\begin{tabular}{|l|l|}
\hline Resposibilities & Collaborators \\
\hline Menampilkan & Mesin Inferensi \\
Pertanyaan & \\
Menjawab Pertanyaan & \\
\hline
\end{tabular}

\section{Desaign GUI}

Pada tahap ini, keseluruhan perancangan secara grafis aplikasi dilakukan. Dalam merancangnya digunakan prinsip-prinsip dari bidang ilmu Interaksi Manusia dan Komputer. Contohnya dalam hal pemilihan warna, besar huruf, kebiasaan pengguna dan lain sebagainya. Tahap ini dimaksudkan agar waktu pengerjaan lebih singkat dan tidak ada dokumentasi yang sia-sia.

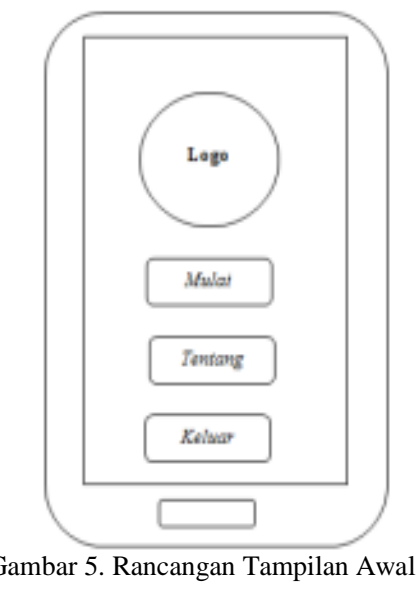




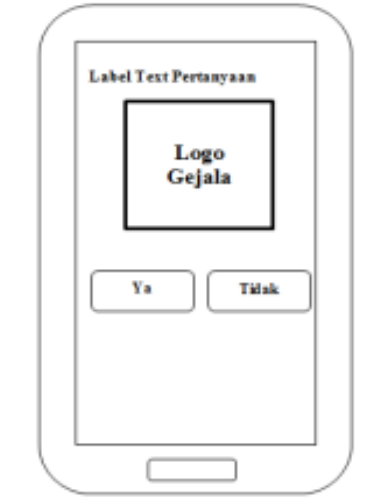

Gambar 6. Rancangan Pertanyaan

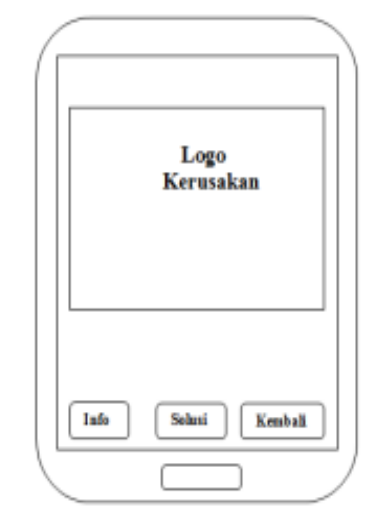

Gambar 7. Rancangan Kesimpulan

\section{Cooding}

Implementasi Aplikasi Sistem Pakar Pendeteksi Kerusakan Handphone menggunakan web open-source App Inventor yang dijalankan pada platform Android.

a. Perancangan Antar Muka di Lingkungan APPInventor

Pada bagian ini, pengembang melakukan perancangan antar muka program melalui komponen App Inventor bernama Designer, dimana di bagian kiri layar terdapat serangkaian palet yang didalamnya terdapat bagian-bagian yang diantaranya adalah label, tombol, textbox, pilihan pengaturan layout, media penyimpanan dan sebagainya. Masing-masing komponen yang diperlukan di drag and drop ke area viewer

b. Penyusunan Kode Blok

Kode blok digunakan untuk menentukan bagaimana behavior atau fungsi dari masing-masing komponen yang telah dirancang pada komponen designer. Penyusunan kode blok juga dengan metode drag and drop dari palet yang berada di bagian kiri layar

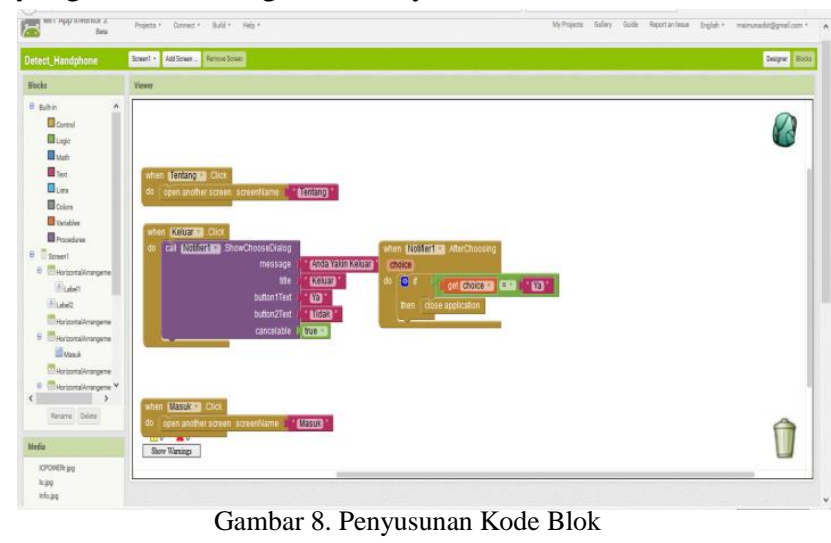

\section{Testing}

Pada tahap ini dilakukan pengujian masing-masing modul (unit) program apakah sesuai dengan tugasnya. Pengetesan ini dilakukan dengan menggunakan metode black box testing yaitu pengetesan menggunakan metode pengujian logika program yiatu perkasus atau masalah yang diajukan. Pada tahap akhir akan diujikan pada kondisi sebenarnya yaitu dengan implementation testing.

1. Black Box Testing

Karena penulis menggunakan extreme programming sebagai model prosesnya maka sebenarnya pengujian hanya dilakukan dengan metode unit testing. Table dibawah merupakan hasil pengujian dengan unit testing.

Tabel 4. Hasil Pengujian dengan Unit Testing

\begin{tabular}{|c|c|c|c|}
\hline No. & $\begin{array}{c}\text { Nama } \\
\text { Pengujian }\end{array}$ & $\begin{array}{l}\text { Hasil Yang } \\
\text { Diharpkan }\end{array}$ & Hasil \\
\hline 1. & $\begin{array}{c}\text { Fungsi menu } \\
\text { pada } \\
\text { halaman } \\
\text { awal }\end{array}$ & $\begin{array}{l}\text { Tiap menu dapat } \\
\text { dijalankan tanpa } \\
\text { pesan error }\end{array}$ & Valid \\
\hline 2. & $\begin{array}{l}\text { Input Data } \\
\text { Pengguna }\end{array}$ & $\begin{array}{c}\text { Sistem mampu } \\
\text { menerima input data } \\
\text { pengguna berupa } \\
\text { nama dan } \\
\text { ciri/karakteristik } \\
\text { untuk proses analisa }\end{array}$ & Valid \\
\hline 3. & $\begin{array}{l}\text { Proses } \\
\text { Analisa }\end{array}$ & $\begin{array}{c}\text { Sistem mampu } \\
\text { menampilkan hasil } \\
\text { analisa berdasarkan } \\
\text { input yang } \\
\text { dimasukkan } \\
\text { pengguna }\end{array}$ & Valid \\
\hline 4. & $\begin{array}{c}\text { Data } \\
\text { "Tentang" } \\
\text { pengguna }\end{array}$ & $\begin{array}{c}\text { Sistem } \\
\text { menampilkan jenis- } \\
\text { jenis kerusakan } \\
\text { yang dibahas dalam } \\
\text { kerusakan } \\
\text { handphone }\end{array}$ & Valid \\
\hline
\end{tabular}

\section{Implementation Testing}

Berikut ini ilustrasi implementasi aplikasi yang berjalan oleh seorang pengguna yakni aplikasi dimulai dengan tampilan awal seperti dibawah ini :

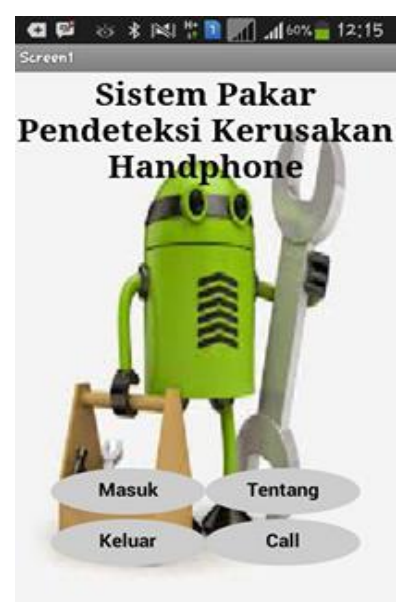

Gambar 9. Tampilan Awal Aplikasi 
Tidak Bisa Cars

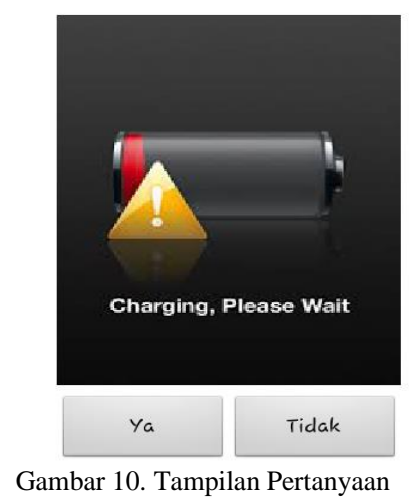

Mesin inferensi kemudian mengolah hasil input dari pengguna, kemudian menarik kesimpulan hasil analisa yaitu jenis kerusakan handphone.
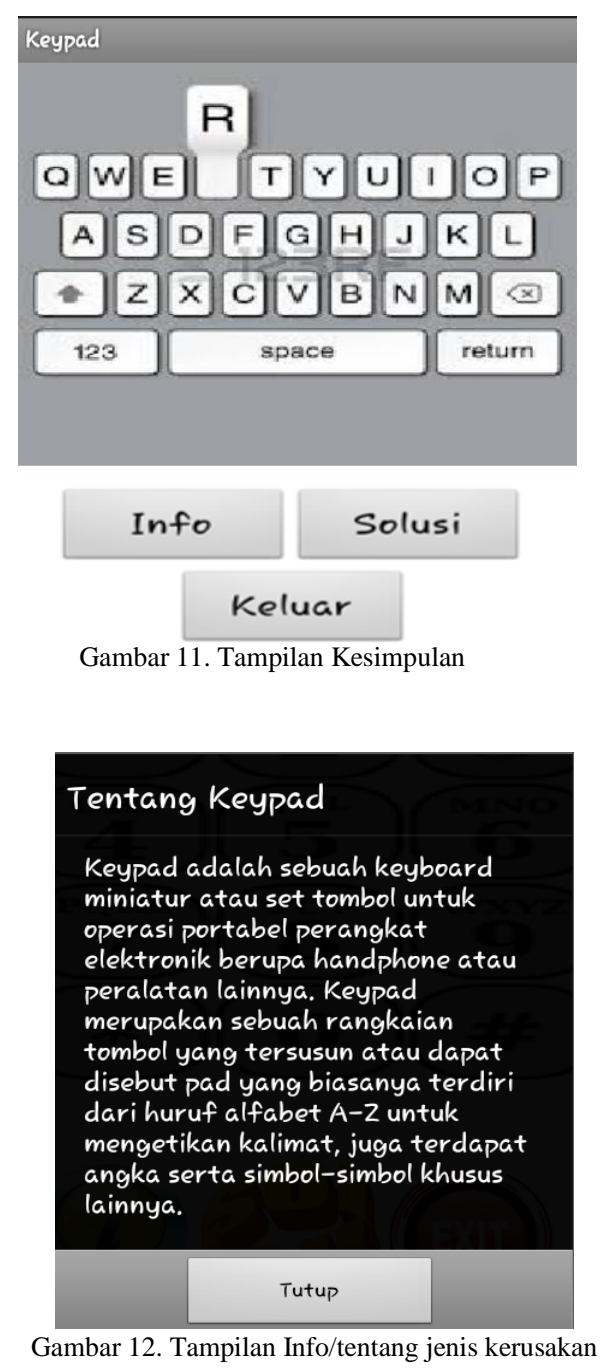

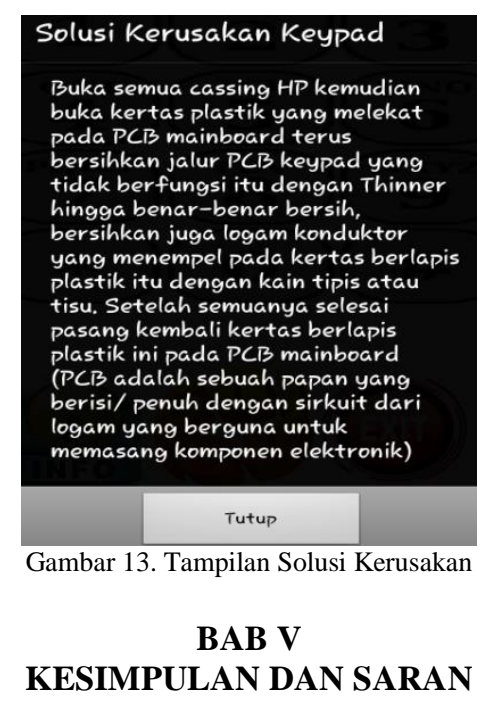

\section{Kesimpulan}

Berdasarkan hasil pengujian dan implementasi sistem pakar pendeteksi kerusakan handphone ini dapat disimpulkan sebagai berikut :

1. Aplikasi sistem pakar Pendeteksi Kerusakan Handphone berbasis Android berjalan dengan baik sesuai rancangan.

2. Metode inferensi Forward Chainning yang digunakan pada penelitian ini menentukan gejalagejala kerusaakan terlebih dahulu, setelah itu dicocokan dengan fakta-fakta dan aturan yang ada dalam basis pengetahuan kemudian menarik kesimpulan berupa jenis kerusakan yang yang terjadi.

Dengan adanya aplikasi sistem pakar ini maka dapat membantu efisiensi waktu dalam memperoleh hasil dari kerusakan-kerusakan yang terjadi pada handphone serta meminimalisir biaya untuk konsultasi ke teknisi. Namun demikian tidak sepenuhnya menggantikan peran pakar (Teknisi) untuk hasil analisa yang lebih

\section{Saran}

Berdasarkan kesimpulan-kesimpulan yang telah dikemukakan, dapat diajukan beberapa saran untuk pengembangan lebih lanjut antara lain :

1. Untuk penelitian selanjutnya agar melakukan perbaikan pengetahuan, untuk meningkatkan keakuratan sistem pakar

2. Jika memungkinkan bagi yang selanjutnya akan mengembangkan sistem pakar menggunakan App Inventor agar menggunakan fasilitas TinyWebDB supaya data dapat disimpan secara terus menerus di database web.

3. Ke depan aplikasi sistem pakar pendeteksi kerusakan handphone dapat didesain dengan menggunakan metode backward chaining untuk data kerusakan lebih kompleks.

\section{DAFTAR PUSTAKA}

[1] Kusumadewi. 2003.Artificial Intelligent (Teknik dan aplikasinya). Edisi Pertama. Yogyakarta: Graha Ilmu.

[2] Pressman, Roger S. 2010. Software Engineering : A Practitioner's Approach, Seventh Edition. Mc Graw Hill Higher Education 
[3] Safaat, Nazzarudin. 2011. Pemrograman Aplikasi Mobile Smartphone dan Tablet PC Berbasis Android. Informatika. Bandung.

[4] Turban, E. 2005. Decision Support System and Intlegence Systems. Yogyakarta: Penerbit Andi Yogyakarta.

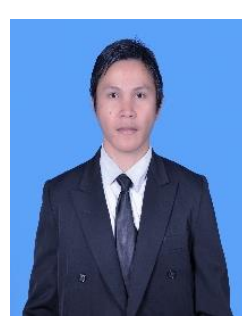

Sekilas dari penulis dengan nama lengkap Mercydian Pangkey, lahir pada tanggal 26 Juni 1991 di Manado. Dengan pendidikan pertama di Taman Kanak-Kanak Nafiri, kemudian melanjutkan ke SD Negeri GMIM 23 Manado, melanjutkan ke SMP Negeri 8 Manado, dan pada tahun 2007 melanjutkan ke SMK Negeri 2 Manado.

Setelah lulus sekolah tingkat kejuruan pada tahun 2010 penulis melanjutkan ke Perguruan Tinggi tepatnya di Universitas Sam Ratulangi Manado, Fakultas Teknik, Jurusan Elektro, Program Studi Teknik Informatika. Penulis membuat skripsi untuk memenuhi syarat sarjana (S1) dengan judul Sistem Pakar Pendeteksi Kerusakan Android Berbasis Android yang di bimbing oleh dua dosen Teknik Informatika yaitu Dr.Eng. Vecky C. Poekoel, ST,MT dan Oktavian A Lantang, ST, MTI sehingga pada tanggal 29 Juni 2016 penulis resmi lulus di Teknik Informatika Universitas Sam Ratulangi Manado. 